\title{
Bioconversion of lignocellulosic waste to bioethanol by Trichoderma and yeast fermentation
}

\author{
K. Saravanakumar $\cdot$ K. Kathiresan
}

Received: 25 May 2013/Accepted: 7 October 2013/Published online: 24 October 2013

(c) The Author(s) 2013. This article is published with open access at Springerlink.com

\begin{abstract}
The present work aimed at producing bioethanol using lignocellulosic waste sawdust and marine yeast fermentation. Lignocellulosic waste materials were converted into monosugars through acid hydrolysis and finally treated with cellulase enzyme derived from Trichoderma/Hypocrea. To enhance the conversion of the glucose from sawdust, the experimental conditions were statistically optimized. The efficient conversion of sawdust to glucose of $78.56 \%$ was achieved under the conditions of $\mathrm{pH} 6.19$, temperature $29{ }^{\circ} \mathrm{C}$, cellulase enzyme $\left(8.16 \mathrm{IU} \mathrm{ml}^{-1}\right)$ and sawdust $\left(7.95 \mathrm{~g}^{-1}\right)$. The lignocellulosic waste-sawdust hydrolysis was used as the carbon source for the production of bioethanol. Bioethanol production of $85.6 \%$ was achieved (55.2 $\mathrm{g} \mathrm{l}^{-1}$ ) under the optimized conditions of temperature of $36.5^{\circ} \mathrm{C}$, incubation time of $102 \mathrm{~h}$ and enzyme-treated sawdust of $45.14 \mathrm{ml} \mathrm{l}^{-1}$ and agitation of $330 \mathrm{rpm}$. This work achieved maximum bioethanol production using H. estonica and $S$. cerevisiae fermentation.
\end{abstract}

Keywords Bioethanol - Marine yeasts - Trichoderma . Lignocellulosic waste $\cdot$ Mangroves

\section{Introduction}

Fuel deficiency is a global issue due to exhaustion of fossil fuel and growing climate change (EC 2003; Wingren et al.

K. Saravanakumar $(\square) \cdot$ K. Kathiresan Faculty of Marine Sciences, Centre of Advanced Study in Marine Biology, Annamalai University, Parangipettai 608502, Tamil Nadu, India

e-mail: saravana732@gmail.com

K. Kathiresan

e-mail: kathirsum@rediffmail.com
2003; Li 2003; Qureshi et al. 2006; Sveinsdottir et al. 2009). In order to overcome this issue, different types of techniques have been invented for the possible conversion of cellulosic waste materials into glucose for the ethanol production, as an alternative way for fuel conservation (Sun and Cheng 2002). The bioconversion of lignocellulosic materials (i.e., agricultural residues, woods, and residues from pulp and paper industries, solid wastes) to bioethanol produces high yield of glucose after hydrolysis (McMillan 1994). The utilization of the lignocellulosic materials for the conversion of the biofuel involves only low cost (Li et al. 2007).

Lignocellulose, the most abundant organic matter in the Earth, can be utilized to produce various renewable fuels and chemicals (Lau et al. 2010). For the digestion of these materials into glucose, many methods have been used such as thermal pretreatments, chemical pretreatments, biological pretreatments and enzymatic pretreatments (Meinita et al. 2012). Cellulolytic and hemicellulolytic enzymes are able to increase monosugars from the digestion of lignocellulose (Pakarinen et al. 2011). For this purpose, fungi in particular Trichoderma species that can produce cellulolytic enzymes are employed (Aro et al. 2005; Rodriguez Gomez et al. 2012). In general, yeasts are potential microorganisms for the production of bioethanol by sugar fermentation (Kathiresan et al. 2011; Senthilraja et al. 2011). However, most of the studies are restricted to microbes of terrestrial origin, but not of marine origin. Hence, the present work was undertaken for the conversion of sawdust (lignocellulosic wastes) to sugars for fuel fermentation using cellulolytic enzymes of the mangrove-derived Trichoderma and further conversion of sugars to bioethanol using the mangrove-derived yeast strain of Saccharomyces cerevisiae. Based on the data, the culture 
conditions were optimized statistically for the enzyme hydrolysis process and bioethanol fermentation.

\section{Materials and methods}

Microorganisms and maintenance

Trichoderma (Hypocrea) species (Trichoderma estonicum/ H. estonica SKS1 JQ611722) and yeasts species (Saccharomyces cerevisiae $\mathrm{JN} 387604$ ) were isolated from mangrove sediment, located in the south east coast of India using selective medium (Askew and Laing 1993) and yeast peptone agar medium (Fell 2005), respectively. The stock cultures were maintained at $4{ }^{\circ} \mathrm{C}$ on slants of potato dextrose agar for H. estonica and yeast peptone agar for S. cerevisiae.

\section{Substrate}

Sawdust was obtained from local wood mills, passed through a $1.5-\mathrm{mm}$ sieve to maintain uniform particle size, washed through distilled water to remove impurities present in it and finally dried at $60{ }^{\circ} \mathrm{C}$ overnight. The sawdust was pre-hydrolyzed using $0.8 \%$ of phosphoric acid by the method of Kathiresan et al. (2011).

\section{Cellulase enzyme production by Hypocrea estonica}

Spore suspension of Hypocrea estonica SKS1 (JQ611722) was used as microbial inoculum for the fermentation. It was prepared by culturing $H$. estonica in potato dextrose agar slant cultures at $30{ }^{\circ} \mathrm{C}$ for 7 days and spore suspension was washed through the Tween- 80 water $(0.02 \% \mathrm{v} / \mathrm{v})$; the suspension was then assessed as final spore count of $2.3 \times 10^{3} \mathrm{CFU} \mathrm{ml}{ }^{-1}$. Then $10 \mathrm{ml}$ of spore suspension was inoculated into a 250-ml Erlenmeyer flask containing $100 \mathrm{ml}$ glucose pre-cultured medium (\%, w/v) (glucose, 3; yeast extract, $0.8 ; \mathrm{K}_{2} \mathrm{HPO}_{4}, 0.4 ; \mathrm{MgSO}_{4} \cdot 7 \mathrm{H}_{2} \mathrm{O}, 0.2 ; \mathrm{pH}$, 7.0) and was cultured at $30{ }^{\circ} \mathrm{C}, 200 \mathrm{rpm}$ for $48 \mathrm{~h}$ in a rotary shaking incubator to prepare the mycelial suspension. At last, mycelial suspension was inoculated into a $250-\mathrm{ml}$ Erlenmeyer flask containing the statistically optimized medium for cellulase production by $H$. estonica (Saravanakumar and Kathiresan 2013a) that consisted of $7.69 \mathrm{~g} \mathrm{l}^{-1}$ of sawdust, $3.59 \mathrm{~g} \mathrm{l}^{-1}$ of $\left(\mathrm{NH}_{4}\right)_{2} \mathrm{SO}_{4}$, under the temperature of $49{ }^{\circ} \mathrm{C}$ at $\mathrm{pH}$ of 8.8 with inoculum size of $6.0 \%$ (v/w) and was cultivated at $30{ }^{\circ} \mathrm{C}$ for $120 \mathrm{~h}$ to produce cellulose.

\section{Determination of cellulase enzyme activity}

$5 \mathrm{ml}$ of the fermented residues was suspended in $150 \mathrm{ml}$ distilled water and shaken at $120 \mathrm{rpm}$ for $2 \mathrm{~h}$. Then the filtrate was centrifuged $(10,000 \mathrm{rpm})$ using a high speed centrifuge for $15 \mathrm{~min}$ and the supernatant was used for enzyme assay using the dinitrosalicylic acid (DNS) method (Miller 1959).

\section{Enzymatic hydrolysis}

Enzymatic hydrolysis was carried out in $125 \mathrm{ml}$ screwcapped Erlenmeyer flasks. Diluted acid-treated sawdust powder was suspended in distilled water in the flasks. Water was added during the pretreatment in such a way so as to maintain the substrate concentration at $15 \%(\mathrm{w} / \mathrm{v})$ after the addition of the crude cellulase enzyme derived from $H$. estonica. Hydrolysis was performed at $50{ }^{\circ} \mathrm{C}$ for $24 \mathrm{~h}$ at $120 \mathrm{rpm}$ in an incubator shaker. $1 \mathrm{ml}$ sample was periodically removed from each flask $(0,2,8,18,24,72,120$, and $168 \mathrm{~h}$ ). Each sample was centrifuged for $10 \mathrm{~min}$ at $13,500 \mathrm{~g}$, and $500 \mu$ supernatant was then removed and placed into a 1.5-ml Eppendorf tube containing the stop buffer $(512 \mathrm{mM}$ $\mathrm{Na}_{2} \mathrm{CO}_{3}$ and $288 \mathrm{mM} \mathrm{NaHCO} 3$; pH 10.0) (Sandhu et al. 2012). The buffered samples were stored at $4{ }^{\circ} \mathrm{C}$ for subsequent glucose measurement; commercial glucose was used as the standard for the percentage calculation.

\section{Bioethanol production by $S$. cerevisiae}

Bioethanol production experiments were carried out according to the experimental setups derived from the center composite design. The enzyme-treated sawdust hydrolysis was used as the carbon source. The percentage of the bioethanol was calculated according to the method of Saravanakumar et al. (2013b).

\section{Determination of bioethanol using gas chromatography}

Concentration of bioethanol in the distillate of culture filtrate was estimated using a Hewlett Packard 5890 Series II gas chromatography with chromosorb 105 column and nitrogen as a carrier gas. The temperature of the injection port, oven and detection port was 250,120 , and $250{ }^{\circ} \mathrm{C}$, respectively. For the analysis, $1 \mu \mathrm{l}$ of liquid samples was injected into gas chromatography. The bioethanol concentration was determined using bioethanol standard plot and is expressed in percentage with help of instrumental default standard value of $65 \mathrm{~g} \mathrm{l}^{-1}$ which is equivalent to $100 \%$ (Saravanakumar and Kathiresan 2013a, 2013b).

\section{Optimization of the enzyme hydrolysis process}

Optimization of the environmental conditions for the maximum hydrolysis process of the sawdust to sugar using 
H. estonica-derived cellulase was studied using 30 runs of statistical model assessed from central composite design of response surface methodology. In this experiment, important factors such as $\mathrm{pH}(6-8)$, temperature $\left(20-50{ }^{\circ} \mathrm{C}\right)$ and cellulase concentration $\left(2-10 \mathrm{IU} \mathrm{ml}^{-1}\right)$ on glucose conversion were studied.

$Y=\beta_{0}+\Sigma_{i} \beta_{i} X_{i}+\Sigma_{i} \beta_{i i} X_{i}^{2}+\Sigma_{i j} \beta_{i j} X_{i} X_{j}$

where $Y$ is the predicted response (glucose), $X_{i}, X_{j}$ the independent variables, $\beta_{0}$ the offset term, $\beta_{i}$ the $i$ th linear coefficient, $\beta_{i i}$ the $i$ th quadratic coefficient and $\beta_{i j}$ is the $i j$ th interaction coefficient. The experimental design in coded and uncoded value is presented in Table 1. In this study, the independent variables are coded as $X_{1}, X_{2}$, and $X_{3}$, Thus, the second-order polynomial equation can be presented as follows:

$$
\begin{aligned}
Y=\beta_{0} & +\beta_{1} X_{1}+\beta_{2} X_{2}+\beta_{3} X_{3}+\beta_{4} X_{4}+\beta_{11} X_{1}^{2}+\beta_{22} X_{2}^{2} \\
& +\beta_{33} X_{3}^{2}+\beta_{44} X_{4}^{2}+\beta_{12} X_{1} X_{2}+\beta_{13} X_{1} X_{3}+\beta_{14} X_{1} X_{4} \\
& +\beta_{23} X_{2} X_{3}+\beta_{24} X_{2} X_{4}+\beta_{34} X_{3} X_{4}
\end{aligned}
$$

Statistical optimization of bioethanol production

In this experiment, S. cerevisiae (JN387604) was selected for optimization. The individual and interaction effects of temperature $\left({ }^{\circ} \mathrm{C}\right)$, incubation time $(0-120 \mathrm{~h})$, and enzymetreated sawdust (10-50 $\left.\mathrm{ml} \mathrm{l}^{-1}\right)$ and agitation (100-500) on bioethanol production were carried out. The maximum yield of bioethanol production was tested using 30 experimental setups derived from a statistical model-central

\begin{tabular}{|c|c|c|c|c|c|c|}
\hline \multirow[t]{2}{*}{ Std } & \multirow[t]{2}{*}{ (A) $\mathrm{pH}$} & \multirow{2}{*}{$\begin{array}{l}\text { (B) Temperature } \\
\left({ }^{\circ} \mathrm{C}\right)\end{array}$} & \multirow{2}{*}{$\begin{array}{l}\text { (C) Cellulase } \\
\text { concentration } \\
\left(\mathrm{IU} \mathrm{ml} \mathrm{m}^{-1}\right)\end{array}$} & \multirow{2}{*}{$\begin{array}{l}\text { (D) Sawdust } \\
\left(\mathrm{mg} \mathrm{l}^{-1}\right)\end{array}$} & \multicolumn{2}{|l|}{ Glucose $(\%)$} \\
\hline & & & & & Experimental & Predicted \\
\hline 1 & 6 & 20 & 2 & 2 & 65.26 & 63.13 \\
\hline 2 & 8 & 20 & 2 & 2 & 52.26 & 44.33 \\
\hline 3 & 6 & 50 & 2 & 2 & 42.56 & 34.68 \\
\hline 4 & 8 & 50 & 2 & 2 & 32.26 & 31.08 \\
\hline 5 & 6 & 20 & 10 & 2 & 53.26 & 52.91 \\
\hline 6 & 8 & 20 & 10 & 2 & 41.23 & 31.96 \\
\hline 7 & 6 & 50 & 10 & 2 & 23.25 & 19.11 \\
\hline 8 & 8 & 50 & 10 & 2 & 15.26 & 13.36 \\
\hline 9 & 6 & 20 & 2 & 10 & 45.65 & 52.32 \\
\hline 10 & 8 & 20 & 2 & 10 & 36.56 & 31.85 \\
\hline 11 & 6 & 50 & 2 & 10 & 35.62 & 36.04 \\
\hline 12 & 8 & 50 & 2 & 10 & 25.65 & 30.77 \\
\hline 13 & 6 & 20 & 10 & 10 & 78.56 & 70.89 \\
\hline 14 & 8 & 20 & 10 & 10 & 35.62 & 48.27 \\
\hline 15 & 6 & 50 & 10 & 10 & 36.56 & 49.26 \\
\hline 16 & 8 & 50 & 10 & 10 & 48.56 & 41.84 \\
\hline 17 & 5 & 35 & 6 & 6 & 68.56 & 67.71 \\
\hline 18 & 9 & 35 & 6 & 6 & 36.56 & 41.49 \\
\hline 19 & 7 & 5 & 6 & 6 & 45.56 & 49.89 \\
\hline 20 & 7 & 65 & 6 & 6 & 15.26 & 15.01 \\
\hline 21 & 7 & 35 & 2 & 6 & 35.26 & 39.03 \\
\hline 22 & 7 & 35 & 14 & 6 & 39.56 & 39.87 \\
\hline 23 & 7 & 35 & 6 & 2 & 12.25 & 27.61 \\
\hline 24 & 7 & 35 & 6 & 14 & 56.56 & 45.28 \\
\hline 25 & 7 & 35 & 6 & 6 & 65.23 & 65.23 \\
\hline 26 & 7 & 35 & 6 & 6 & 65.23 & 65.23 \\
\hline 27 & 7 & 35 & 6 & 6 & 65.23 & 65.23 \\
\hline 28 & 7 & 35 & 6 & 6 & 65.23 & 65.23 \\
\hline 29 & 7 & 35 & 6 & 6 & 65.23 & 65.23 \\
\hline 30 & 7 & 35 & 6 & 6 & 65.23 & 65.23 \\
\hline
\end{tabular}
composite design of response surface methodology. The

Table 1 Center composite design of response surface methodology for the glucose production of experimental and predicted responses 
Table 2 Center composite design of response surface methodology for the bioethanol production of experimental and predicted response

\begin{tabular}{|c|c|c|c|c|c|c|}
\hline \multirow[t]{2}{*}{ Std } & \multirow{2}{*}{$\begin{array}{l}\text { (A) Temperature } \\
\left({ }^{\circ} \mathrm{C}\right)\end{array}$} & \multirow{2}{*}{$\begin{array}{l}\text { (B) Incubation } \\
\text { time }\end{array}$} & \multirow{2}{*}{$\begin{array}{l}\text { (C) Enzyme-treated } \\
\text { sawdust }\left(\mathrm{ml} \mathrm{l}^{-1}\right)\end{array}$} & \multirow{2}{*}{$\begin{array}{l}\text { (D) Agitation } \\
(\mathrm{rpm})\end{array}$} & \multicolumn{2}{|c|}{ Bioethanol yield (\%) } \\
\hline & & & & & Experimental & Predicted \\
\hline 1 & 0 & 0 & 10 & 100 & 0.00 & 4.71 \\
\hline 2 & 50 & 0 & 10 & 100 & 0.00 & 9.51 \\
\hline 3 & 0 & 120 & 10 & 100 & 15.69 & 19.99 \\
\hline 4 & 50 & 120 & 10 & 100 & 75.56 & 82.40 \\
\hline 5 & 0 & 0 & 50 & 100 & 0.00 & 4.24 \\
\hline 6 & 50 & 0 & 50 & 100 & 0.00 & 8.58 \\
\hline 7 & 0 & 120 & 50 & 100 & 15.65 & 19.09 \\
\hline 8 & 50 & 120 & 50 & 100 & 85.65 & 81.04 \\
\hline 9 & 0 & 0 & 10 & 500 & 0.00 & 21.21 \\
\hline 10 & 50 & 0 & 10 & 500 & 0.00 & 18.69 \\
\hline 11 & 0 & 120 & 10 & 500 & 12.26 & 25.81 \\
\hline 12 & 50 & 120 & 10 & 500 & 68.56 & 80.92 \\
\hline 13 & 0 & 0 & 50 & 500 & 0.00 & 15.28 \\
\hline 14 & 50 & 0 & 50 & 500 & 0.00 & 12.30 \\
\hline 15 & 0 & 120 & 50 & 500 & 12.36 & 19.45 \\
\hline 16 & 50 & 120 & 50 & 500 & 56.69 & 74.10 \\
\hline 17 & 25 & 60 & 30 & 300 & 15.58 & -1.97 \\
\hline 18 & 75 & 60 & 30 & 300 & 78.65 & 57.47 \\
\hline 19 & 25 & 60 & 30 & 300 & 19.65 & -8.25 \\
\hline 20 & 25 & 180 & 30 & 300 & 79.65 & 68.82 \\
\hline 21 & 25 & 60 & 10 & 300 & 75.26 & 49.04 \\
\hline 22 & 25 & 60 & 70 & 300 & 54.26 & 41.75 \\
\hline 23 & 25 & 60 & 30 & 100 & 15.26 & 16.12 \\
\hline 24 & 25 & 60 & 30 & 700 & 65.26 & 25.67 \\
\hline 25 & 25 & 60 & 30 & 300 & 75.60 & 75.60 \\
\hline 26 & 25 & 60 & 30 & 300 & 75.60 & 75.60 \\
\hline 27 & 25 & 60 & 30 & 300 & 75.60 & 75.60 \\
\hline 28 & 25 & 60 & 30 & 300 & 75.60 & 75.60 \\
\hline 29 & 25 & 60 & 30 & 300 & 75.60 & 75.60 \\
\hline 30 & 25 & 60 & 30 & 300 & 75.60 & 75.60 \\
\hline
\end{tabular}

coded values of the fermentation factors were determined by the following equation:

$Y=\beta_{0}+\Sigma_{i} \beta_{i} X_{i}+\Sigma_{i} \beta_{i i} X_{i}^{2}+\Sigma_{i j} \beta_{i j} X_{i} X_{j}$

where $Y$ is the predicted response, $X_{i}, X_{j}$ the independent variables, $\beta_{0}$ the offset term, $\beta_{i}$ the $i$ th linear coefficient, $\beta_{i i}$ the $i$ th quadratic coefficient and $\beta_{i j}$ is the $i j$ th interaction coefficient. The experimental design in coded and uncoded value is presented in Table 2 . In this study, the independent variables are coded as $X_{1}, X_{2}, X_{3}$ and $X_{4}$. Thus, the secondorder polynomial equation can be presented as follows:

$$
\begin{aligned}
Y=\beta_{0} & +\beta_{1} X_{1}+\beta_{2} X_{2}+\beta_{3} X_{3}+\beta_{4} X_{4}+\beta_{11} X_{1}^{2}+\beta_{22} X_{2}^{2} \\
& +\beta_{33} X_{3}^{2}+\beta_{44} X_{4}^{2}+\beta_{12} X_{1} X_{2}+\beta_{13} X_{1} X_{3}+\beta_{14} X_{1} X_{4} \\
& +\beta_{23} X_{2} X_{3}+\beta_{24} X_{2} X_{4}+\beta_{34} X_{3} X_{4}
\end{aligned}
$$

A statistical program package Design Expert 8.0.6 was used for regression and model fit analysis of the data was obtained, and then estimated the coefficient of the regression equation, and analyzed the variance of selected factors and model significance.

\section{Results}

Effect of the cellulase enzyme on sawdust hydrolysis process

The interaction and individual effects of the experimental condition on hydrolysis process were studied by adopting the statistical design of the center composite model of 30 
experimental setups and are presented in Table 1 along with the predicted and experimental responses of glucose production. The acceptability of the statistical model was tested by the quadratic model along with the contour error plot for the predicted and experimental responses and further model fitness tested by the normal standardized residual plot. The standard error value of 0.43 showed fitness for the acceptable model and $R^{2}$ value of the model was 0.87 which also proved the $87 \%$ of model fitness. The application of the response surface methodology based on the estimates of the parameters indicated an experimental relationship between the response and input variables with the glucose production expressed in the following quadratic mode:

$$
\begin{aligned}
\text { Glucose }(\%)= & 65.23-6.56 X_{1}-8.72 X_{2}+0.21 X_{3}+4.42 X_{4} \\
& +3.80 X_{1} X_{2}-0.54 X_{1} X_{3}-0.42 X_{1} X_{4} \\
& -1.34 X_{2} X_{3}+3.04 X_{2} X_{4}+7.20 X_{3} X_{4}-2.66 X_{1}^{2} \\
& -8.19 X_{2}^{2}-6.44 X_{3}^{2}-7.20 X_{4}^{2}
\end{aligned}
$$

where $X_{1}(\mathrm{pH}), X_{2}$ (temperature), $X_{3}$ (cellulase) and $X_{4}$ (agitation) are independent variables. Significance of each coefficient is presented in Eq. (5), determined by the Student's $t$ test and $p$ values (Montgomery 2001). The ANOVA results of the quadratic model for glucose production are given in Table 3 . The value of $R^{2}$ and adjusted $R^{2}$ was close to 0.87 and it revealed a high correlation between the observed values and the predicted values. This means that regression model provides an excellent explanation of the relationship between the independent variables (factors) and the response (glucose production). The lack-of-fit term was non-significant as it was desired. The non-significant value of lack-of-fit observed (0.856) was more than probability of 0.05 and this revealed that the quadratic model was valid for the present study.

In this case, the individual and interaction effects on the hydrolysis process were tested and the data are presented in Table 3 . The factors of the $X_{1}, X_{2}, X_{4}, X_{3} X_{4}, X_{2}^{2}, X_{3}^{2}, X_{4}^{2}$ were significant but other factors and their interaction effects were not significant on the glucose production $(p<0.05)$.

The optimization of the specific conditions for the glucose production was assessed. Statistically optimized conditions for the efficient sawdust hydrolysis process of glucose production were $\mathrm{pH}(6.19)$, temperature $\left(29^{\circ} \mathrm{C}\right)$, cellulase enzyme $\left(8.16 \mathrm{IU} \mathrm{ml}^{-1}\right)$ and sawdust (7.95 $\mathrm{mg} \mathrm{l}^{-1}$ ). This hydrolysed glucose was used further for the alcohol production as the carbon source.

\section{Optimization of bioethanol production by $S$. cerevisiae}

The interaction and individual effects of experimental

\begin{tabular}{|c|c|c|c|c|c|}
\hline Source & $\begin{array}{l}\text { Sum of } \\
\text { squares }\end{array}$ & $d f$ & $\begin{array}{l}\text { Mean } \\
\text { square }\end{array}$ & $F$ value & $\begin{array}{l}p \text { value } \\
\text { prob }>F\end{array}$ \\
\hline Model & $8,011.377$ & 14 & 572.2412 & 7.290321 & $0.0002 * * *$ \\
\hline (A) $\mathrm{Ph}$ & $1,031.233$ & 1 & $1,031.233$ & 13.13785 & $0.0025 * *$ \\
\hline $\begin{array}{l}\text { (B) Temperature } \\
\left({ }^{\circ} \mathrm{C}\right)\end{array}$ & $1,824.922$ & 1 & $1,824.922$ & 23.2494 & $0.0002 * * *$ \\
\hline $\begin{array}{l}\text { (C) Cellulase } \\
\text { concentration } \\
\left(\mathrm{IU} \mathrm{m} \mathrm{m}^{-1}\right)\end{array}$ & 1.075267 & 1 & 1.075267 & 0.013699 & $0.9084^{\mathrm{NS}}$ \\
\hline $\begin{array}{l}\text { (D) Sawdust } \\
\left(\mathrm{mg} \mathrm{l}^{-1}\right)\end{array}$ & 468.6968 & 1 & 468.6968 & 5.971171 & $0.0274 *$ \\
\hline $\mathrm{AB}$ & 231.04 & 1 & 231.04 & 2.943437 & $0.1068^{\mathrm{NS}}$ \\
\hline $\mathrm{AC}$ & 4.6225 & 1 & 4.6225 & 0.05889 & $0.8115^{\mathrm{NS}}$ \\
\hline $\mathrm{AD}$ & 2.7889 & 1 & 2.7889 & 0.03553 & $0.8530^{\mathrm{NS}}$ \\
\hline $\mathrm{BC}$ & 28.6225 & 1 & 28.6225 & 0.364649 & $0.5550^{\mathrm{NS}}$ \\
\hline $\mathrm{BD}$ & 148.1089 & 1 & 148.1089 & 1.886899 & $0.1897^{\mathrm{NS}}$ \\
\hline $\mathrm{CD}$ & 828.8641 & 1 & 828.8641 & 10.55968 & $0.0054 * *$ \\
\hline $\mathrm{A}^{2}$ & 193.6786 & 1 & 193.6786 & 2.467455 & $0.1371^{\mathrm{NS}}$ \\
\hline $\mathrm{B}^{2}$ & $1,841.955$ & 1 & $1,841.955$ & 23.4664 & $0.0002 * * *$ \\
\hline $\mathrm{C}^{2}$ & $1,139.255$ & 1 & $1,139.255$ & 14.51405 & $0.0017 * *$ \\
\hline $\mathrm{D}^{2}$ & $1,420.334$ & 1 & $1,420.334$ & 18.09498 & $0.0007 * * *$ \\
\hline Residual & $1,177.399$ & 15 & 78.49328 & & \\
\hline Lack-of-fit & $1,177.399$ & 10 & 117.7399 & & $0.856^{\mathrm{NS}}$ \\
\hline Pure error & 0 & 5 & 0 & & \\
\hline Cor total & $9,188.776$ & 29 & & & \\
\hline
\end{tabular}
conditions on bioethanol production process were studied
Table 3 Analysis of variance for the response of glucose production by $H$. estonica

$N S$ not significant

*** $p<0.001 ; * * p<0.01 ; * p<0.05$

by adopting the statistical design of the center composite for the bioethanol production. The acceptability of the statistical model was tested by the quadratic model along with the contour error plot for the predicted and experimental responses. The standard error value of the 0.43 showed fitness for the acceptable model and $R^{2}$ value of the model of 0.81 also proved $81 \%$ of model fitness. The application of the response surface methodology based on the estimates of the parameters indicated an experimental relationship between the response and input variables, which is expressed in the following quadratic model:

$$
\begin{gathered}
\text { Bioethanol yield }(\%)=75.60+14.86 X_{1}+19.27 X_{2} \\
-1.82 X_{3}+2.39 X_{4}+14.41 X_{1} X_{2}-0.12 X_{1} X_{3} \\
-0.83 X_{1} X_{4}-0.11 X_{2} X_{3}-2.67 X_{2} X_{4}-2.67 X_{3} X_{4} \\
-11.96 X_{1}^{2}-11.33 X_{2}^{2}-7.55 X_{3}^{2}-13.68 X_{4}^{2}
\end{gathered}
$$

where $X_{1}$ (temperature), $X_{2}$ (incubation time), $X_{3}$ (enzymetreated sawdust) and $X_{4}$ (agitation) are independent variables. Significance of each coefficient is presented in Eq. (6), determined by the Student's $t$ test and $p$ values 
(Montgomery 2001). The ANOVA results of the quadratic model for bioethanol production are given in Table 4 . The value of $R^{2}$ and adjusted $R^{2}$ was close to 0.81 and it revealed a high correlation between the observed values and the predicted values. This means that regression model provides an excellent explanation of the relationship between the independent variables (factors) and the response (bioethanol production). The lack-of-fit term was non-significant. The non-significant value of lack-of-fit observed (0.52) was more than probability of 0.05 and this revealed that the quadratic model was valid for the present study.

In this case, the individual and interaction effects on the hydrolysis process were tested and the data are presented in Table 4 . The factors of the $X_{1}, X_{2}, X_{1} X_{2}, X_{1}^{2}, X_{2}^{2}, X_{3}^{2}, X_{4}^{2}$ were significant but other factors and their interaction effects were not significant on the bioethanol production $(p<0.05)$.

The optimization of the specific conditions for the bioethanol production was assessed. Statistically optimized conditions for the efficient bioethanol production process were temperature of $36.5^{\circ} \mathrm{C}$, incubation time of $102 \mathrm{~h}$ and

Table 4 Analysis of variance for the response of bioethanol production by $S$. cerevisiae

\begin{tabular}{|c|c|c|c|c|c|}
\hline Source & $\begin{array}{l}\text { Sum of } \\
\text { squares }\end{array}$ & $d f$ & $\begin{array}{l}\text { Mean } \\
\text { square }\end{array}$ & $F$ value & $\begin{array}{l}p \text { value } \\
\text { prob }>F\end{array}$ \\
\hline Model & $28,097.22$ & 14 & $2,006.944$ & 4.824282 & $0.0023 * *$ \\
\hline $\begin{array}{l}\text { (A) Temperature } \\
\left({ }^{\circ} \mathrm{C}\right)\end{array}$ & $5,299.67$ & 1 & $5,299.67$ & 12.73932 & $0.0028 * *$ \\
\hline $\begin{array}{l}\text { (B) Incubation } \\
\text { hours }\end{array}$ & $8,909.677$ & 1 & $8,909.677$ & 21.41704 & $0.0003 * * *$ \\
\hline $\begin{array}{l}\text { (C) Enzyme- } \\
\text { treated sawdust } \\
\left(\mathrm{ml} \mathrm{l}^{-1}\right)\end{array}$ & 79.64327 & 1 & 79.64327 & 0.191446 & $0.6680^{\mathrm{NS}}$ \\
\hline $\begin{array}{l}\text { (D) Agitation } \\
\text { (rpm) }\end{array}$ & 136.8993 & 1 & 136.8993 & 0.329078 & $0.5747^{\mathrm{NS}}$ \\
\hline $\mathrm{AB}$ & $3,320.641$ & 1 & $3,320.641$ & 7.982139 & $0.0128 *$ \\
\hline $\mathrm{AC}$ & 0.2116 & 1 & 0.2116 & 0.000509 & $0.9823^{\mathrm{NS}}$ \\
\hline $\mathrm{AD}$ & 53.4361 & 1 & 53.4361 & 0.128449 & $0.7250^{\mathrm{NS}}$ \\
\hline $\mathrm{BC}$ & 0.1849 & 1 & 0.1849 & 0.000444 & $0.9835^{\mathrm{NS}}$ \\
\hline $\mathrm{BD}$ & 113.8489 & 1 & 113.8489 & 0.273669 & $0.6085^{\mathrm{NS}}$ \\
\hline $\mathrm{CD}$ & 29.75703 & 1 & 29.75703 & 0.07153 & $0.7928^{\mathrm{NS}}$ \\
\hline$A^{2}$ & $3,924.794$ & 1 & $3,924.794$ & 9.4344 & $0.0078 * *$ \\
\hline $\mathrm{B}^{2}$ & $3,519.94$ & 1 & $3,519.94$ & 8.461214 & $0.0108 *$ \\
\hline$C^{2}$ & $1,563.842$ & 1 & $1,563.842$ & 3.759156 & $0.0716^{\mathrm{NS}}$ \\
\hline $\mathrm{D}^{2}$ & $5,129.922$ & 1 & $5,129.922$ & 12.33128 & $0.0031 * *$ \\
\hline Residual & $6,240.133$ & 15 & 416.0088 & & \\
\hline Lack-of-fit & $6,240.133$ & 10 & 624.0133 & & $0.52^{\mathrm{NS}}$ \\
\hline Pure error & 0 & 5 & 0 & & \\
\hline Cor total & $34,337.35$ & 29 & & & \\
\hline
\end{tabular}

NS not significant

*** $p<0.001 ; * * p<0.01 ; * p<0.05$ enzyme-treated sawdust of $45.14 \mathrm{ml} \mathrm{l}^{-1}$ and agitation of $330 \mathrm{rpm}$.

\section{Discussion}

Bioethanol production from the lignocellulosic waste materials depends on the treatment of the sawdust and removal of the hemicelluloses and lignin from the sawdust for the production of monosugars such as glucose. This is a challenge to the current researchers on the renewable fuel production (Meinita et al. 2012). Marine-derived Trichoderma is a highly potential source for the bioprospecting research (Saravanakumar and Kathiresan 2012). These marine Trichoderma strains were used in this work. The present study successfully attempted the pretreatment of the sawdust with $0.8 \%$ phosphoric acid followed by enzyme hydrolysis using $H$. estonica-derived cellulase for the maximum production of monosugars and then conversion of bioethanol by fermentation with yeast ( $S$. cerevisiae).

Statistically optimized conditions for the efficient sawdust hydrolysis process were $\mathrm{pH}$ (6.19), temperature $\left(29^{\circ} \mathrm{C}\right)$, cellulase enzyme $\left(8.16 \mathrm{IU} \mathrm{ml}^{-1}\right)$ and $8 \%$ phosphoric acid-treated sawdust $\left(7.95 \mathrm{mg}^{-1}\right)$. For suitability of each pre-hydrolysis treatment for maximum solubilization of hemicelluloses and lignin, the effect of pre-hydrolysis treatment of sawdust with the enzyme was investigated using $H$. estonica-derived cellulase enzyme. It resulted in maximum yield of glucose $(78.56 \%)$. The significant conversion of the sawdust to the monosugars (glucose) was attained at temperature above $29^{\circ} \mathrm{C}$. This is due to the fact that high temperature increases hemicellulose degradation and lignin transformation, thus increasing the potential of cellulose hydrolysis ( $\mathrm{Li}$ et al. 2009), whereas low temperature increases the solubilization of the hemicellulose (Sun and Cheng 2002). Addition of dilute acid in steam treatment can effectively improve enzymatic hydrolysis, decrease the production of inhibitory compounds, and lead to more removal of hemicelluloses (Martin et al. 2002; Kathiresan et al. 2011; Matsushita et al. 2010; Wang et al. 2009).

Saravanakumar and Kathiresan (2013a, b) have reported the potential of the marine strain over the terrestrial yeast strains and achieved the maximum yield of the bioethanol of $69.58 \%$ under optimal conditions of temperature at $30{ }^{\circ} \mathrm{C}$, sawdust concentration of $6.84 \mathrm{mg} \mathrm{l}^{-1}$ under the agitation speed of $360 \mathrm{rpm}$ in $89 \mathrm{~h}$ of incubation. Similarly, the present study attained maximum bioethanol production of $85.6 \%$ under the optimized conditions of temperature of $36.5{ }^{\circ} \mathrm{C}$, incubation time of $102 \mathrm{~h}$ and enzyme-treated sawdust of $45.14 \mathrm{ml} \mathrm{l}^{-1}$ and agitation of $330 \mathrm{rpm}$; little variations of the optimized conditions were 
attributed due to the higher availability of monosugars in the Trichoderma-derived enzyme-treated sawdust hydrolysis. Thus, the temperature has a significant role in the bioethanol production by increasing the enzyme hydrolysis of the sawdust concentration and also the bioethanol yield due to increased production of fermentable monosugars (Fromanger et al. 2010; Zuroff and Curtis 2012). The present work suggested that the maximum production of the bioethanol from the sawdust could be achieved by proper method of acid and enzyme pretreatment and yeast fermentation employing $H$. estonica and $S$. cerevisiae.

Acknowledgments The authors are thankful to the authorities of Annamalai University, India and to Ministry of Human Resource Development, Govt. of India, New Delhi.

Conflict of interest The authors declare that they have no conflict of interest.

Open Access This article is distributed under the terms of the Creative Commons Attribution License which permits any use, distribution, and reproduction in any medium, provided the original author(s) and the source are credited.

\section{References}

Aro N, Pakula T, Penttiillae M (2005) Transcriptional regulation of plant cell wall degradation by filamentous fungi. FEMS Microbiol Rev 29:719-739

Askew DJ, Laing MD (1993) An adapted selective medium for the quantitative isolation of Trichoderma sp. Plant Pathol 42: 686-690

Fell JW (2005) The role of nucleotide analysis in the systematics of the yeast genera Cryptococcus sp. and Rhodotorula sp. Stud Mycol 38:129-146

Fromanger R, Guillouet SE, Uribelarrea JL, Molina-Jouve C, Cameleyre X (2010) Effect of controlled oxygen limitation on Candida shehatae physiology for ethanol production from xylose and glucose. J Ind Microbiol Biotechnol 37:437-445

Kathiresan K, Saravanakumar K, Senthilraja P (2011) Bio-ethanol production by marine yeasts isolated from coastal mangrove sediment. Int Multidiscip Res J 1(1):19-24

Lau MJ, Lau MW, Gunawan C, Dale BE (2010) Ammonia fiber expansion (AFEX) pretreatment, enzymatic hydrolysis and fermentation on empty palm fruit bunch fiber (EPFBF) for cellulosic ethanol production. Appl Biochem Biotechnol 162: $1847-1857$

Li K (2003) The role of enzymes and mediators in lignocellulose degradation. In: Goodell B, Nicholas D, Schultz T (eds) American Chemical Society Symposium Series 845. Wood deterioration and preservation, advances in our changing world. American Chemical Society, Washington, DC, pp 196-209

Li A, Antizar-Ladislao B, Khraisheh M (2007) Bioconversion of municipal solid waste to glucose for bioethanol production. Bioprocess Biosyst Eng 30(3):189-196

Li XH, Yang HJ, Roy B, Wang D, Yue WF, Jiang LJ, Park EY, Miao YG (2009) The most stirring technology in future: cellulose enzyme and biomass utilization. Afr J Biotechnol 8:2418-2422

Martín C, Galbe M, Wahlbom CF, Hagerdal BH, Jonsson LJ (2002) Ethanol production from enzymatic hydrolysates of sugarcane bagasse using recombinant xylose-utilising Saccharomyces cerevisiae. Enz Microb Technol 31:274-282

Matsushita Y, Yamauchi K, Takabe K, Awano T, Yoshinaga A, Kato M, Kobayashi T, Asada T, Furujyo A, Fukushima K (2010) Enzymatic saccharification of Eucalyptus bark using hydrothermal pretreatment with carbon dioxide. Biores Technol 101: 4936-4939

Mcmillan JD (1994) Fuels production In: Himmel ME, Baker JO, Overend RP (eds) ACS symposium series 566. American Chemical Society, Washington, DC, pp 292-324

Meinita MD, Hong YK, Jeong GT (2012) Comparison of sulfuric and hydrochloric acids as catalysts in hydrolysis of Kappaphycus alvarezii (cottonii). Bioprocess Biosyst Eng Jan 35(1-2):123

Miller GL (1959) Use of DNS reagent for the measurement of reducing sugar. Anal Chem 31:426-428

Montgomery DC (2001) Design and analysis of experiments, 5th edn. John Wiley and Sons, New York

Pakarinen A, Zhang J, Brock T, Maijala P, Viikari L (2011) Enzymatic accessibility of fiber hemp is from GH families 10 and 11 with thermostable cellulases in lignocellulose hydrolysis. 108(12):2823-2834

Qureshi TA, Mirbahar KB, Samo MU, Soomro NM, Solangi AA, Memon A (2006) Clinical study of experimentally induced anaphylactic shock in goats. Int J Pharmacol 2:357-361

Rodriguez Gomez D, Lehmann L, Olkjar et al (2012) Examining the potential of plasma-assisted pretreated wheat straw for enzyme production by Trichoderma reesei. Appl Biochem Biotechnol 166(8):2051-2063 (Data provider: Technical University of Denmark Document type)

Sandhu H, Nidumolu U, Sandhu S (2012) Assessing risks and opportunities arising from ecosystem change in primary industries using ecosystem-based business risk analysis tool. Hum Ecol Risk Assess 18(1):47-68

Saravanakumar K, Kathiresan K (2012) Bioprospecting potential of marine-derived Trichoderma. Asian Pac J Trop Biomed 1-8

Saravanakumar K, Kathiresan K (2013a) Thermostable cellulase produced by trichoderma (Hypocrea estonica). J Biotechnol Sci $1(1): 22-41$

Saravanakumar K, Senthilraja P, Kathiresan K (2013b) Bioethanol production by mangrove derived marine yeast, Sacchromyces cerevisiae King Saud University Journal of King Saud University-Science http://dx.doi.org/10.1016/j.jksus.2012.12.005

Senthilraja P, Kathiresan K, Saravanakumar K (2011) Comparative analysis of bioethanol production by different strains of immobilized marine yeast. J Yeast Fungal Res 2(8):113-116

Sherrard EC, Harris EE (1932) Factors influencing properties of isolated wood lignin. Ind Eng Chem 24:103

Sun Y, Cheng J (2002) Hydrolysis of lignocellulosic material from ethanol production: a review. Bioresour Technol 83:1-11

Sveinsdottir M, Baldursson SRB, Orlygsson J (2009) Ethanol production from monosugars and lignocellulosic biomass by thermophilic bacteria isolated from Icelandic hot springs. Icelandic Agric Sci 22:45-58

Wang Y, Sakamoto Y, Kamiya Y (2009) Remediation of actual groundwater polluted with nitrate by the catalytic reduction over copper-palladium supported on active carbon. Appl Catal A 361:123-129

Wingren A, Galbe M, Zacchi G (2003) Techno economic evaluation of producing ethanol from softwood: comparison of $\mathrm{SSr}$ and SHF and identification of bottlenecks. Biotechnol Prog 19:1109-1117

Zuroff TR, Curtis WR (2012) Development of symbiotic consortia for lignocellulosic biofuel production. Appl Microbiol Biotechnol 93:1423-1435 